\title{
PERBEDAAN PENGARUH METODE PEMBELAJARAN KOOPERATIF TIPE NUMBERED HEADS TOGETHER (NHT) DAN METODE CERAMAH TERHADAP HASIL BELAJAR PKN PADA SISWA KELAS XI IPS SMA NEGERI I PABELAN KECAMATAN PABELAN KAB. SEMARANG SEMESTER GANJIL TAHUN AJARAN 2012/2013
}

\author{
Novi Istiani \\ Alumni Program Studi S1 PPKn \\ FKIP - Universitas Kristen Satya Wacana \\ Henny Dewi K. \\ Program Studi S1 PPKn \\ FKIP - Universitas Kristen Satya Wacana \\ Bambang S. Sulasmono \\ Program Studi S1 PPKn \\ FKIP Universitas Kristen Satya Wacana
}

\begin{abstract}
ABSTRAK
Penelitian ini bertujuan untuk mengetahui perbedaan pengaruh antara metode pembelajaran kooperatif tipe NHT dan metode ceramah terhadap hasil belajar PKn pada siswa kelas XI IPS SMA Negeri I Pabelan. Sampel dalam penelitian ini adalah siswa kelas XI IPS 2 dan XI IPS 3 yang berjumlah 40 siswa. Penelitian ini merupakan penelitian eksperimen, dengan desain penelitian Postest Only Control Design yaitu dalam pengambilan dua kelompok yang masing-masing dipilih secara random. Teknik tes merupakan teknik utama dalam pengumpulan data, dimana instrumen soal telah diuji validitas dan realibilitasnya. Analisis data dalam penelitian ini menggunakan analisis data $\mathrm{Uji}_{\mathrm{test}}$ dengan bantuan program penghitungan statistik SPSS 18.0 for Windows. Hasil analisis Uji $\mathrm{T}_{\text {test }}$ antara kedua metode pembelajaran kooperatif tipe NHT dan metode ceramah terhadap hasil belajar PKn sebesar -4,919 termasuk pada tingkat signifikan 0,000 pada level 0,05 2-tailed, yang berarti signifikan karena nilai lebih kecil dari 0,05 atau $(0,000<0,05)$. Rata-rata dari kelas eksperimen sebesar 83,35 dan kelas kontrol sebesar 76,65 sehingga perbedaan rata-rata pada kedua kelas adalah 6,70. Dari hasil penelitian tersebut dapat disimpulkan bahwa terdapat perbedaan pengaruh antara metode pembelajaran kooperatif tipe NHT dan metode ceramah terhadap hasil belajar PKn pada siswa kelas XI IPS SMA Negeri I Pabelan Kecamatan Pabelan Kabupaten Semarang semester ganjil tahun ajaran 2012/2013, sehingga guru diharapkan semakin meningkatkan kreatifitasnya dalam menciptakan proses pembelajaran yang mampu membangkitkan semangat kerja sama dan hasil belajar siswa dengan penggunaaan berbagai metode pembelajaran. Salah satunya guru dapat menggunakan metode pembelajaran kooperatif tipe NHT untuk meningkatkan kerjasama dan hasil belajar siswa.
\end{abstract}

Kata Kunci: Metode NHT, Metode Ceramah.

\section{PENDAHULUAN}

Salah satu masalah dalam dunia pendidikan yang dihadapi saat ini adalah masalah lemahnya proses pembelajaran. Wina Sanjaya (2006) menyatakan bahwa dalam proses pembelajaran, anak kurang didorong untuk mengembangkan kemampuan berpikir. Proses pembelajaran yang masih terjadi saat ini lebih banyak menggunakan metode ceramah dimana dalam orientasi proses pengajaran lebih pada guru (teacher centered), siswa sebagai objek belajar dan komunikasi yang terjadi bersifat satu arah saja sehingga menyebabkan siswa pasif dan merasa bosan dengan pelajaran yang disampaikan oleh guru. 
Djoko dan Herawati (2009) menyatakan bahwa pembelajaran dengan metode ceramah membuat siswa cenderung pasif dan tidak dapat mengemukakan pendapatnya sehingga hasil belajar siswa tidak optimal. Di samping itu metode ceramah membuat siswa cepat bosan dan mengantuk sehingga perhatian siswa tidak tertuju pada materi yang diajarkan. Namun pada kenyataannya, metode ceramah masih banyak digunakan oleh guru karena adanya tuntutan untuk menyelesaikan materi pembelajaran tepat pada waktunya.

Di lain pihak pembelajaran yang dapat membuat siswa antusias dalam belajar, kreatif, kritis dan saling bekerjasama adalah pembelajaran kooperatif. Pada dasarnya metode pembelajaran kooperatif merupakan bentuk pembelajaran dengan cara siswa belajar dan bekerja sama dalam kelompok-kelompok kecil secara kolaboratif yang anggotanya terdiri dari empat sampai enam orang dengan struktur kelompok yang bersifat heterogen (Rusman, 2011).

Pembelajaran kooperatif terdiri atas banyak metode yang dapat diterapkan yaitu diantaranya STAD, Jigsaw, TGT (Team Games Tounament), Group Investigation (GI), Think Pair Share (TPS) dan Numbered Heads Together (Trianto,2010). Salah satunya yang akan dipakai dalam penelitian ini adalah metode pembelajaran kooperatif tipe Numbered Head Together (NHT). NHT merupakan jenis pembelajaran kooperatif yang dirancang untuk mempengaruhi pola interaksi siswa dan dikembangkan untuk melibatkan lebih banyak siswa dalam menelaah materi yang tercakup dalam suatu pelajaran dan mengecek pemahaman mereka terhadap isi pelajaran (Trianto,2010). Dengan metode ini, siswa belajar melaksanakan tanggung jawab pribadinya dalam saling keterkaitan dengan rekan-rekan kelompoknya. Metode pembelajaran kooperatif tipe NHT ini dapat meningkatkan hasil belajar siswa yang rendah menjadi lebih tinggi dibandingkan dengan metode ceramah (Ibrahim Muslimin, 2000).

Berdasarkan latar belakang masalah, dirumuskan masalah penelitian apakah ada perbedaan pengaruh yang signifikan antara Metode Pembelajaran Kooperatif Tipe NHT dan
Metode Ceramah terhadap hasil belajar PKn pada siswa kelas XI IPS SMA Negeri I Pabelan Kecamatan Pabelan Kabupaten Semarang Semester Ganjil Tahun Ajaran 2012/2013.

Penelitian ini dilakukan dengan tujuan untuk Mengetahui perbedaan pengaruh antara metode pembelajaran kooperatif tipe NHT dan Metode Ceramah terhadap hasil belajar PKn pada siswa kelas XI IPS SMA Negeri IPabelan Kecamatan Pabelan Kabupaten Semarang Semester Ganjil Tahun Ajaran 2012/2013.

Metode penelitian ini adalah metode penelitian eksperimen dengan desain penelitian yang digunakan adalah "Posttest- Only Control Design”. Dalam rancangan tersebut terdapat dua kelompok yang masing-masing dipilih secara random/acak (R) untuk sampel, yaitu kelompok A dan kelompok B. Kelompok A diberi perlakuan (X) dan kelompok B tidak diberi perlakuan (Sugiyono, 2011)

\section{HASIL BELAJAR}

Menurut Dimyati dan Mudjiono (2006), hasil belajar merupakan hal yang dapat dipandang dari dua sisi yaitu sisi siswa dan dari sisi guru. Dari sisi siswa, hasil belajar merupakan tingkat perkembangan mental yang lebih baik bila dibandingkan pada saat sebelum belajar. Tingkat perkembangan mental tersebut terwujud pada ranah kognitif, afektif, dan psikomotorik. Sedangkan dari sisi guru, adalah bagaimana guru bisa menyampaikan pembelajaran dengan baik dan siswa bisa menerimanya.Untuk mengetahui hasil belajar siswa biasanya guru melakukan tes atau ulangan setelah terselesaikannya bahan pelajaran.

\section{Metode Pembelajaran Kooperatif Tipe NHT}

NHT merupakan jenis pembelajaran kooperatif yang dirancang untuk mempengaruhi pola interaksi siswa dan sebagai alternatif terhadap struktur kelas tradisional. NHT dikembangkan untuk melibatkan lebih banyak siswa dalam menelaah materi yang tercakup dalam suatu pelajaran dan mengecek pemahaman mereka terhadap isi pelajaran (Trianto, 2010). 
Adapun sintaks/langkah-langkah dari tipe pembelajaran ini adalah (1) guru membagi siswa ke dalam kelompok 3-5 orang dan setiap anggota kelompok diberikan nomor 1 sampai 5, (2) guru mengajukan sebuah pertanyaan kepada siswa. Pertanyaan dapat bervariasi, (3) Siswa menyatukan pendapatnya terhadap jawaban pertanyaan itu dan meyakinkan tiap anggota dalam timnya mengetahui jawaban timnya, (4) Guru memanggil suatu nomor tertentu kemudian siswa yang nomornya sesuai mengacungkan tangannya dan mencoba untuk menjawab pertanyaan untuk seluruh kelas.

Pembelajaran kooperatif tipe NHT merupakan salah satu tipe pembelajaran kooperatif yang menekankan pada struktur khusus yang dirancang untuk mempengaruhi pola interaksi siswa dan memiliki tujuan untuk meningkatkan penguasaan akademik (Herdian, 2009).

\section{Metode Ceramah}

Metode ceramah adalah suatu cara penyajian bahan ajar atau cara mengajar melalui penjelasan atau penuturan secara lisan oleh guru kepada peserta didik (Widi Rahardjo, 2002). Dalam pembelajaran dengan ceramah guru menjadi pusat informasi dan lalu lintas komunikasi/ pembicaraan hanya searah yaitu dari guru kepada siswa. Sehubungan itu agar berhasil dengan baik maka guru harus mempuyai keterampilan menerangkan dengan kata-kata yang menarik, jelas, mudah diterima siswa akan lebih baik lagi apabila ditopang dengan media pengajaran yang tepat.

Adapun langkah-langkah metode ceramah adalah sebagai berikut: (1) Persiapan: Pada tahap persiapan awal berceramah, guru melakukan kegiatan-kegiatan antara lain: menata secara sistematis/mengorganisir bahan pelajaran yang akan disajikan, menentukan urut-urutan penyajian, agar bagi guru ataupun siswa dapat dengan mudah memahami dan menguasai bahan pelajaran tersebut. (2) Awal Ceramah: kripsu sebagai pengantar/introduksi dimana guru membuka pelajaran dengan kegiatan-kegiatan antara lain: menumbuhkan motivasi dan perhatian siswa dengan sikap yang antusias, hangat, mendorong rasa ingin tahu dengan pernyataan yang menantang/merangsang berpikir siswa dengan mengemukakan pokok-pokok isi/materi. (3) Pelaksanaan ceramah: kegiatan inti/utama dimana guru menyajikan bahan pelajaran yang telah dipersiapkan pada siswa di kelas. (4) Akhir ceramah: kegiatan akhir dari guru dalam menerapkan metode ceramah yaitu dengan membuat kesimpulan/ rangkuman secara garis besar dari isi pelajaran yang baru saja dijelaskan, dapat dilakukan oleh guru atau siswa.

\section{ANALISIS DESKRIPIF KELAS EKSPERIMEN DAN KONTROL}

Data hasil belajar kelas eksperimen setelah mendapat perlakuan dengan metode kooperatif tipe NHT mempunyai nilai rata-rata 83,35 dengan nilai terendah 77 dan nilai tertinggi 90 . Sedangkan data hasil belajar kelas kontrol setelah mendapat perlakuan dengan metode ceramah mempunyai nilai rata-rata 76,65 dengan nilai terendah 70 dan nilai tertinggi 83 .

Dalam penelitian ini dilakukan analisis deskriptif untuk memberikan gambaran data tentang jumlah data, minimum, maksimum, mean dan standar deviasi yang digambarkan dalam tabel 1 berikut

Tabel 1 Hasil Deskriptif Kelas Eksperimen dan Kelas kontrol Descriptive Statistics

\begin{tabular}{|c|c|c|c|c|c|}
\hline \multicolumn{6}{|c|}{ Descriptive Statistics } \\
\hline & & Minimum & Maximum & Mean & Std. Deviation \\
\hline Kelas_Kontrol & 20 & 70,00 & 83,00 & 76,6500 & 4,04286 \\
\hline Kelas_Eksperimen & 20 & 77,00 & 90,00 & 83,3500 & 4,55695 \\
\hline Valid N (listwise) & 20 & & & & \\
\hline
\end{tabular}




\section{Hasil Uji Normalitas}

Uji normalitas dilakukan pada hasil belajar berdasarkan metode pembelajaran yang digunakan dan kemampuan siswa setelah melalui proses pembelajaran. Dalam penelitian ini uji normalitas menggunakan uji Kolmogorov-Smirnov dengan taraf signifikansi kelas eksperimen adalah 0,086 $(0,086>5 \%)$ dan taraf signifikansi kelas kontrol adalah $0,073(0,073>5 \%)$ sehingga data terdistribusi normal.

\section{Hasil Uji Homogenitas}

Dalam penelitian ini uji homogenitas menggunakan uji Levene Statistic. Berdasarkan pengujian homogenitas kelas ekperimen dan kontrol diperoleh taraf signifikansinya adalah 0,439 . Karena hasil perolehan pengujian ini lebih besar 0,05 maka varian kelas eksperimen dan kontrol adalah homogen.

\section{Analisis Uji T- test $_{\text {}}$}

Berdasarkan hasil uji Independent Samples T-Test yang dapat dilihat pada kolom t-test for Equality of Means pada tabel diatas diketahui nilai thitung hasil belajar PKn untuk kelas eksperimen dan nilai t hitung hasil belajar PKn kelas kontol sebesar -4,919 dengan nilai signifikasi (2- tailed) sebesar 0,000. Dalam penelitian ini pengujian hipotesis dilakukan untuk menguji hipotesis nol
$\left(\mathrm{H}_{0}\right)$ yang menyatakan tidak terdapat perbedaan variabel.

Pada hasil uji Independent Samples T-Test yang dapat dilihat pada kolom $t$-test for Equality of Means diperoleh koefesien t hitung sebesar 4,919 dan nilai signifikasi sebesar 0,000. Sementara skor $\mathrm{t}$ tabel dilihat berdasarkan distribusi t yang dicari pada á $=5 \%: 2=2,5 \%$ (uji 2 tailed) dengan derajat kebebasan (df) sebesar $38(\mathrm{df}=40-2)$. Berdasarkan hasil derajat kebebasan yang dilihat pada $t$ tabel diperoleh nilai sebesar 1,686. Maka dapat diketahui bahwa nilai -t hitung < -t tabel $(-4,919<-1,686))$ maka diartikan bahwa $\mathrm{H}_{0}$ ditolak.

Oleh dikarenakan $\mathrm{H}_{0}$ ditolak berdasarkan pada nilai -t hitung < -t tabel $(-4,919<-1,686)$ maka $\mathrm{H}_{1}$ yang menyatakan bahwa ada perbedaan pengaruh yang signifikan antara pembelajaran kooperatif tipe Numbered Heads Together (NHT) dan metode ceramah terhadap hasil belajar PKn pada siswa kelas XIIPS SMA N I Pabelan semester ganjil tahun pelajaran 2012/2013 diterima.

Berdasarkan pengujian tersebut, maka $\mathrm{H}_{0}$ ditolak dan $\mathrm{H}_{1}$ diterima yang berarti bahwa penggunaan metode pembelajaran yang diterapkan pada kelas eksperimen, yaitu metode pembelajaran kooperatif tipe Numbered Heads Together (NHT) dan ceramah pada kelas kontrol terdapat perbedaan yang signifikan. Hasil pengujian ini membuktikan bahwa hipotesis ini diterima dan benar.

Tabel 2 Hasil Perbandingan nilai rata-rata dua variabel bebas Independent Samples Test

\begin{tabular}{llrr}
\multicolumn{5}{c}{ Independent Samples Test } \\
\hline
\end{tabular}




\section{Hasil Penelitian}

Hasil menunjukkan ada perbedaan pengaruh yang signifikan antara metode pembelajaran kooperatif tipe NHT dan metode ceramah terhadap hasi belajar PKn. Hal ini dapat diketahui uji Independent Sample T-Test diketahui nilai t hitung kelas XI IPS sebesar -4,919. Dari analisis uji Independent Sample T-Test kemudian dilakukan uji hipotesis penelitian. Berdasarkan uji Independent Sample T-Test diketahui nilai -t hitung $<-\mathrm{t}$ tabel $(-4919<-1686)$ maka diartikan bahwa $\mathrm{H}_{0}$ ditolak dan $\mathrm{H}_{1}$ diterima.

Hasil penelitian ini juga menunjukkan bahwa rata-rata kelas eksperimen lebih tinggi dibandingkan dengan kelas kontrol yaitu $83,35>76,65$ dengan selisih 6,7 poin. Secara teoritis metode NHT dikembangkan untuk melibatkan lebih banyak siswa dalam menelaah materi yang tercakup dalam suatu pelajaran dan mengecek pemahaman mereka terhadap isi pelajaran. NHT juga mendorong siswa untuk bekerja sama dalam kelompok, bertanggung jawab, dan berpartisipasi aktif dalam kelompok. NHT dapat meningkatkan hasil belajar siswa dibandingkan dengan metode ceramah.

\section{KESIMPULAN}

Berdasarkan hasil penelitian dan pembahasannya dapat disimpulkan bahwa ada perbedaan pengaruh yang signifikan antara metode kooperatif tipe NHT dan metode ceramah terhadap hasil belajar PKn siswa SMA N I Pabelan kelas XI IPS 2 dan XI IPS 3 semester ganjil tahun 2012/2013.

Berdasarkan nilai rata-rata dan nilai tertinggi menunjukkan bahwa penggunaan metode kooperatif tipe NHT dalam pembelajaran PKn menghasilkan hasil belajar yang lebih baik dibandingkan dengan metode ceramah.

\section{DAFTAR PUSTAKA}

Dimyanti dan Mudjiono. 2006. Belajar dan Pembelajaran. Jakarta: Rineka Cipta.

Djoko Dwi K. dan Popy Herawati. 2009. Jurnal Penelitian Kependidikan: Penerapan Pembelajaran Kooperatif Numbered Head Together (NHT) Untuk Meningkatkan Hasil Belajar Siswa Pada Mata Diklat Manajemen Perkantoran Kelas XAPK di SMK Ardjuna 01 Malang. Malang: Fakultas Ekonomi Universitas Negeri Malang.

Herdian. 2009. Model Pembelajaran NHT (Numbered Head Together), (Online), http:/ /herdy07.wordpress.com/2009/04/22/ model-pembelajaran-nht-numbered-headtogether/. Diakses tanggal 24 Nopember 2012.

Ibrahim, M, dkk. 2000. Pembelajaran Kooperatif. Surabaya: Universitas Negeri Surabaya University Press.

Rahardja, Widi. 2002. Sekitar Strategi Belajar Mengajar dan Keterampilan Mengajar. Salatiga: Fakultas Ekonomi UKSW.

Rusman. 2011. Model-model Pembelajaran Mengembangkan Profesionalisme Guru. Jakarta: PT Raja Grafindo Persada.

Sanjaya, Wina. 2006. Strategi Pembelajaran Berorientasi Standar Proses Pendidikan. Jakarta: Kencana.

Sugiyono. 2011. Metode Penelitian Kuantitatif, Kualitatif dan R\&D. Bandung: Alfabeta.

Trianto. 2010. Mendesain Model Pembelajaran Inovatif- Progresif. Jakarta: Kencana.

Undang-Undang No.20 Tahun 2003 tentang Sistem Pendidikan Nasional. 